\title{
PREDIKSI FINANCIAL DISTRESS: RASIO KEUANGAN DAN SENSITIVITAS MAKROEKONOMI PERUSAHAAN SEKTOR PRIMER
}

\author{
Sumani \\ Sumanisumani69@gmail.com \\ Fakultas Ekonomidan Bisnis Universitas Jember
}

\begin{abstract}
ABASTRAC
The objective of this research is to analyze the ability of macroeconomic proxied by the sensitivity of exchange rate and interest rate, and the ability of financial ratios proxied by current ratio (CR); return on assets (ROA); total asset turnover (TATO); debt to asset ratio (DAR); and sales growth (GROWTH), in predicting financial distress in primary sector companies in Indonesia. The population was 42 primary sector companies in Indonesia from the agricultural sector and mining sector listed on the Indonesia Stock Exchange. By employing a purposive sampling technique, the sample consisted of 39 companies, i.e., 9 agricultural companies and 30 mining companies in the 10 years range of the study from 2008 to 2018. Data were analyzed using logistic regression analysis. Results showed that ROA and DAR variables can be used to predict a company's financial distress. However, the exchange rate variable proxied by exchange rate sensitivity, interest rate variable proxied by interest rate sensitivity, $C R$, TATO, and GROWTH cannot be used to predict financial distress.
\end{abstract}

Key words: financial distress; financial ratio; and sensitivity of macroeconomc.

\begin{abstract}
ABSTRAK
Tujuan penelitian, yaitu untuk menganalisis kemampuan makroekonomi yang diproksikan dengan sensitivitas nilai tukar dan suku bunga, dan rasio keuangan yang diproksikan dengan current ratio (CR), return on asset (ROA), total asset turnover (TATO), debt to asset ratio (DAR) dan sales growth (GROWTH) dalam memprediksikan financial distress pada perusahaan sektor primer di Indonesia. Populasi dalam penelitian ini adalah perusahaan sektor primer, baik sektor pertanian maupun sektor pertambangan yang terdaftar di BEI dan berjumlah sebanyak 42 perusahaan. Metode yang digunakan dalam penentuan sampel adalah purposive sampling. Perusahaan sektor primer yang memenuhi kriteria sampel sebanyak 39 perusahaan, dimana 9 perusahaan sektor pertanian dan 30 perusahaan sektor pertambangan dengan rentang waktu penelitian selama 10 tahun, tahun 2008-2018. Metode penelitian menggunakan Analisis Regresi Logistik. Hasil penelitian menunjukkan bahwa variabel Return on Asset dan Debt to Asset Ratio dapat digunakan untuk memprediksi kondisi financial distress perusahaan, sedangkan variabel Nilai Tukar yang diproksikan dengan sensitivitas nilai tukar, Suku Bunga yang diproksikan dengan sensitivitas suku bunga, Current Ratio, Total Asset Turnover dan Sales Growth tidak dapat memprediksi kondisi financial distress.
\end{abstract}

Kata kunci : financial distress; rasio keuangan; dan sensitivitas makroekonomi

\section{PENDAHULUAN}

Kondisi perekonomian yang melemah dan krisis global yang terjadi dapat mempengaruhi kinerja perusahaan, baik secara langsung maupun tidak langsung. Artha et al., (2014) menjelaskan bahwa faktor makroekonomi, seperti suku bunga, harga minyak dunia, dan kurs rupiah berpengaruh signifikan terhadap harga saham sektor pertanian di Indonesia. Akbar et al. (2016), juga menunjukkan nilai tukar dan suku bunga berpengaruh negatif signifikan terhadap IHSG sektor pertanian. Hasil penelitian Bubic dan Hajnrih (2012) menegaskan terdapat efek negatif dari krisis ekonomi pada kegiatan operasi perusahaan agribisnis di Vojvodina periode 2008-2010. Kerugian keuangan dan kebutuhan pinjaman untuk menjaga likui- 
ditas dan solvabilitas telah menyebabkan dampak buruk pada struktur dan kinerja keuangan perusahaan.

Sektor primer merupakan sektor utama, dan berkontribusi paling besar pada perekonomian negara-negara berkembang, terutama di Indonesia. Namun, di sektor ini mengalami penurunan jumlah pekerja yang beroperasi, hal ini seiring dengan perkembangan negara tersebut menjadi negara maju. Laporan Kebijakan Moneter Triwulan III 2018, dimana kinerja Lapangan Usaha (LU) sektor Primer melambat dari tahun ke tahun, walaupun kinerja LU sektor pertambangan dan penggalian mengalami peningkatan (Departemen Kebijakan Ekonomi dan Moneter, 2018).

Badan Pusat Statistik (2018), menunjukkan bahwa jumlah penduduk bekerja triwulan I/2018, terbanyak berdasarkan lapangan pekerjaan berada di Sektor Primer (Pertanian, Kehutanan dan Perikanan), sebanyak 30,46 persen. Hanya saja banyaknya jumlah tenaga kerja tidak didukung upah rata-rata pekerjanya. Rata-rata upah pekerjanya sangat kecil, yaitu sebesar Rp. 1,761 juta perbulan. Sektor Primer lainnya (sektor pertambangan dan penggalian) memiliki upah rata-rata perbulan tertinggi, sebesar Rp. 4,127 juta.

Ketika perusahaan mengalami banyak hambatan dan mengalami kerugian yang tidak dapat diatasi, maka lambat laun perusahaan tersebut akan berada pada kondisi financial distress, yaitu kondisi dimana perusahaan tidak memiliki kapasitas untuk memenuhi kewajibannya kesemua pihak, baik bank, vendors maupun pihak ketiga lainnya (Andrade dan Kaplan, 1998). Gejala awal terjadinya financial distress dimungkinkan perusahaan melakukan income smoothing, yaitu merupakan salah satu tindakan manajemen laba, selain minimisasi laba dan maksimalisasi laba (Scott, 2015). Menurut Rahel dan Kristanti (2018), beberapa perusahaan pada sektor pertanian (agriculture) diindikasikan melakukan praktek perataan laba (income smoothing) tahun 2013 - 2017.
Brealy dan Myers (2000: 136), menyatakan bahwa variabel keuangan yang paling banyak digunakan dalam menganalisis kondisi financial distress yaitu rasio keuangan. Menurut Platt dan Platt (2002), current ratio dan return on asset adalah rasio keuangan yang mendominasi dalam memprediksi financial distress. Current ratio dan return on asset memiliki pengaruh negatif signifikan terhadap financial distress suatu perusahaan, dimana semakin tinggi current ratio dan return on asset, maka semakin kecil kemungkinan perusahaan mengalami financial distress.

Total asset turnover juga dapat memprediksi terjadinya financial distress suatu perusahaan (Yap, 2012; Koech et al., 2018). Hasil penelitian Yap (2012), juga menjelaskan rasio keuangan yang diproksikan dengan debt to asset ratio dapat digunakan dalam memprediksi kondisi financial distress, semakin tinggi debt to asset ratio, semakin menujukkan bahwa sebagian besar asset perusahaan tersebut dibiayai oleh utang, hal ini tentu akan menjadi pemicu terjadinya financial distress dalam suatu perusahaan karena semakin besar beban yang ditanggung oleh perusahaan untuk menutupi kewajiban serta bunga yang dibebankan. Menurut Yulpa (2017) debt to asset ratio tidak berpengaruh terhadap financial distress, karena nilai debt to asset ratio yang tinggi belum tentu menandakan suatu perusahaan yang memiliki beban tinggi sehingga laba yang dihasilkan rendah, akan tetapi dimungkinkan bila nilai debt to asset ratio tinggi tidak diikuti dengan beban yang semakin tinggi sehingga perusahaan dapat menghasilkan laba yang tinggi pula dan terhindar dari resiko financial distress.

Hasil penelitian Widarjo dan Setiawan (2009), variabel sales growth tidak memiliki pengaruh yang signifikan terhadap kondisi financial distress. Namun, Raissa dan Mariana (2017) menunjukkan bahwa rasio pertumbuhan (sales growth) memiliki pengaruh yang signifikan terhadap kondisi financial distress perusahaan. 
Penelitian Hanifah (2013) bahwa corporate governance, rasio likuiditas yang diproksikan dengan current ratio, rasio profitabilitas yang diproksikan dengan return on asset, serta rasio aktivitas yang diproksikan dengan total asset turnover berpengaruh negatif signifikan dan dapat memprediksi kondisi financial distress. Made dan Lely (2015) juga menunjukkan bahwa variabel rasio likuiditas, operating capacity dan sales growth memiliki pengaruh negatif dan signifikan dalam memprediksi financial distress, sedangkan leverage tidak mampu memprediksi financial distress. Nurhidayah dan Fitriyatur (2017) menjelaskan bahwa current ratio, return on investment dan net profit margin memiliki hasil signifikan dan berpengaruh positif dalam memprediksi financial distress.

Variabel mikro perusahaan sendiri tidaklah cukup dalam menjelaskan kondisi financial distress yang dialami suatu perusahaan. Hal ini disebabkan kondisi makroekonomi yang selalu berfluktuasi merupakan contoh dari suatu resiko sistematis yang dapat memengaruhi sejumlah besar asset perusahaan (Ross dan Westerfield, 2005 : 830). Selain itu hasil penelitian Bhattacharjee dan Han (2014), Ruhomaun et al. (2019) menunjukkan bahwa baik faktor mikroekonomi, ketidakstabilan faktor makroekonomi dan karakteristik institusional yang berbeda dapat menjadi prediktor finnancial distress dan kinerja perusahaan.

Menurut Karim (2010:135) nilai tukar juga memiliki peranan yang penting dalam pengambilan keputusan untuk berbelanja maupun membeli barang dari luar negeri, karena dengan adanya nilai tukar kita dapat mengetahui harga-harga barang dari berbagai negara ke dalam mata uang negara kita sendiri. Selanjutnya Menurut Rodoni dan Herni (2014:197), semakin tinggi fluktuasi nilai tukar yang bersangkutan, maka investor patut untuk mempertimbangkan pula premi resiko atas nilai tukar tersebut. Dengan demikian dapat diasumsikan bila sensitivitas perusahaan terhadap nilai tukar mempengaruhi kondisi financial distress perusahaan. Sama halnya dengan variabel mikro, dalam penggunaan variabel makro, juga masih terdapat perbedaan hasil antara peneliti satu dengan yang lain. Hasil penelitian Kunt dan Detragiache (1997), Endang dan Jumyetti (2017) menunjukkan bahwa suku bunga memiliki pengaruh yang signifikan terhadap kondisi financial distress, karena ketika suku bunga naik akan memberikan beban operasional bagi perusahaan, tetapi menurut Darmawan (2017) dengan menggunakan variabel makro (suku bunga), menunjukkan bahwa suku bunga tidak memiliki pengaruh yang signifikan terhadap financial distress.

Sulaksana (2016) menjelaskan bahwa nilai tukar memiliki pengaruh positif dan signifikan terhadap kondisi financial distress. Namun hasil penelitian Kunt dan Detragiache (1997) nilai tukar yang berfluktuasi dan surplus GDP tidak memiliki pengaruh yang signifikan terhdadap krisis perbankan. Kondisi ini dipertegas oleh hasil penelitian Nurhidayah dan Fitriyatur (2017) bahwa nilai tukar tidak memiliki pengaruh terhadap kondisi financial distress. Dengan mempertimbangkan beberapa fenomena di atas, maka tujuan penelitian ini, untuk menganalisis kemampuan makroekonomi yang diproksikan dengan sensitivitas nilai tukar dan sensitivitas suku bunga, dan rasio keuangan yang diproksikan dengan current ratio (CR), return on asset ( $R O A)$, total asset turnover (TATO), debt to asset ratio (DAR) dan sales growth (GROWTH) dalam memprediksikan financial distress pada perusahaan sektor primer di Indonesia.

\section{TINJAUAN TEORETIS \\ Teori Sinyal}

Teori sinyal melandasi penelitian ini, teori sinyal digunakan untuk menjelaskan bahwa laporan keuangan digunakan untuk memberi sinyal positive (good news) maupun sinyal negative (bad news) kepada pemakainya. Tuvaratragool (2013) melakukan penelitian tentang pengaturan perbandingan rasio keuangan dalam memberi sinyal 
adanya financial distress dengan menggunakan teknik multi ukur (IMM) yang terdiri dari emerging market, skor model, analisis komparatif rasio, dan analisis tren rasio dan model logit sebagai benchmarking ukuran, hasil penelitian ini menunjukkan bahwa informasi laporan keuangan dapat dijadikan media untuk mengetahui sinyal adanya kegagalan perusahaan.

Ross (1977) menyatakan ketika perusahaan menerbitkan utang baru, menjadi tanda atau sinyal bagi pemegang saham dan investor tentang prospek perusahaan di masa depan. Teori signalling ini muncul karena adanya permasalahan asimetris informasi, karena kondisi asimetris informasi ada dari waktu ke waktu, perusahaan harus menjaga kapasitas cadangan pinjaman dengan menjaga tingkat pinjaman yang rendah. Adanya cadangan ini memungkinkan manajer untuk mengambil keuntungan dari kesempatan investasi, tanpa harus menjual saham pada harga rendah sehingga akan mengirimkan sinyal yang sangat memengaruhi harga saham.

Myers dan Majluf (1984) juga membuat model signalling yang merupakan kombinasi dari keputusan investasi dan keputusan pendanaan. Manajer diasumsikan mengetahui nilai "sebenarnya" perusahaan di masa depan. Disamping itu, manajer juga diasumsikan bertindak sesuai dengan kepentingan dari pemegang saham lama, yaitu orang yang memiliki saham di perusahaan dan berhak atas hak pengambilan suaran dalam Rapat Umum Pemegang Saham (RUPS).

\section{Trade off Theory}

Teori trade off menentukan struktur modal optimal menggunakan beberapa faktor antara lain pajak, biaya keagenan (agency costs) dan biaya kesulitan keuangan (financial distress), tetapi tetap mempertahankan asumsi efisiensi pasar dan symmetric information sebagai penyeimbang dan manfaat penggunaan utang. Tingkat utang yang optimal tercapai ketika penghematan pajak (tax shields) mencapai jumlah yang maksimal terhadap biaya kesulitan keuangan (costs of financial distress). Teori trade off memiliki implikasi bahwa manajer akan berpikir dalam kerangka trade off antara penghematan pajak dan biaya kesulitan keuangan dalam penentuan struktur modal. (Brigham dan Houston, 2007).

\section{Teori Biaya Keagenan (Agency Cost Theory)}

Teori agensi diperkenalkan oleh Berle dan Means (1932) dalam Dewi (2015:65), menyatakan bahwa sebuah organisasi atau perusahaan yang mempekerjakan agen untuk bekerja atas nama perusahaan, dan alasan mengapa para pekerja tidak selalu berkinerja dengan baik seperti yag diharapkan oleh pemberi kerja adalah karena kepentingan dari pekerja dan pemberi kerja tidak berada dalam keselarasan yang sempurna. Teori agensi merupakan hubungan antar keagenan yang terjadi ketika satu individu atau lebih (principal) mempekerjakan orang lain (agen) untuk memberikan suatu jasa dan kemudian mendelegasikan wewenang pengembalian keputusan kepada agen tersebut (Dewi, 2015:66). Selanjutnya juga dijelaskan bahwa masalah keagenan dapat menyebabkan terjadinya biaya keagenan (agency cost). Tentunya apabila biaya keagenan yang dikeluarkan perusahaan terlalu besar, maka tidak menutup kemungkinan perusahaan akan mengalami financial distress.

\section{Financial Distress}

Financial distress merupakan suatu kondisi ketika perusahaan tidak mampu untuk mengelola dan menjaga kestabilan kinerja keuangan yang berawal dari kegagalan perusahaan dalam memasarkan produk yang dibuat, sehingga berakibat pada menurunnya nilai penjualan (Platt dan Platt, 2006). Namun, financial distress sendiri dapat dijadikan "early warning" bagi sistem perusahaan sebagai tanda terjadinya masalah. Oleh karena itu, perusahaan yang mengalami financial distress lebih awal dapat memiliki banyak waktu untuk melakukan perbaikan (Rodoni dan Herni, 2014:189). 
Wruck (1990) mengatakan financial distress merupakan situasi dimana arus kas operasi suatu perusahaan tidak mencukupi dalam memenuhi kewajiban perusahaan dan perusahaan dituntut untuk melakukan kegiatan perbaikan. Adanya financial distress menyebabkan perusahaan melalaikan kontrak dan akan terlibat pada restrukturisasi keuangan antar perusahaan, kreditur dan hak kekayaan investor. Hofer (1980) dan Whitaker (1999) juga menjelaskan bahwa financial distress terjadi saat perusahaan mengalami penurunan kondisi keuangan dari kondisi sebelumnya dan selama beberapa tahun perusahaan mengalami laba bersih (net operating income) negatif. Selain itu menurut Almilia (2003) menyatakan bahwa kondisi financial distress dapat terjadi pada perusahaan yang selama dua tahun mengalami laba bersih negatif. Dengan demikian financial distress merupakan suatu kondisi dimana perusahaan sedang mengalami kondisi kesulitan yang ditunjukkan selama dua tahun memperoleh laba bersih negatif dan apabila tidak dilakukan upaya perbaikan, maka dapat terjadi kebangkrutan.

\section{Determinan Financial Distress}

Dwijayanti (2010) mengungkapkan bahwa terdapat 3 (tiga) alasan utama mengapa perusahaan bisa mengalami financial distress dan kemudian mengalami bangkrut, yaitu:

1) Neoclassical Model. Finnacial distress dan kebangkrutan dapat terjadi jika alokasi sumber daya dalam perusahaan tidak tepat sasaran. Manajemen yang kurang mampu dalam mengalokasikan aset dalam perusahaan untuk kegiatan operasional perusahaan.

2) Financial Model. Pencampuran aset berjalan baik sedangkan struktur keuangan berjalan buruk dengan liquidity constraints. Dapat disimpulkan bahwa walaupun perusahaan dapat bertahan dalam jangka panjang namun perusahaan harus bangkrut dalam jangka pendek.

3) Corporate Governance Model. Kebangkrutan memiliki campuran aset dan struktur keuangan yang baik namun dikelola dengan cara yang buruk. Hal ini dapat mendorong perusahaan menjadi out of the market sebagai akibat dari masalah dalam tata kelola perusahaan yang tidak terdapat jalan keluarnya.

Menurut Rodoni dan Herni (2014:189190), terdapat tiga keadaan yang dapat memicu terjadinya financial distress ditinjau dari aspek keuangan, yaitu:

1) Faktor kekurangan modal

Ketika terjadi ketidakseimbangan aliran penerimaan dana yang bersumber dari penjualan maupun piutang dengan pengeluaran dana guna membiayai kegiatan operasional perusahaan, maka akan dapat mengancam perusahaan berada pada kondisi tidak likuid.

2) Tingginya beban utang dan bunga

Permasalahan likuiditas suatu perusahaan dapat teratasi dalam beberapa rentang waktu ketika perusahaan mampu mendapatkan asupan dana dari pihak luar, seperti pinjaman dari bank. Akan tetapi dalam hal ini, akan muncul permasalahan baru yakni adanya kewajiban untuk membayar kembali pokok pinjaman beserta bunga kreditnya. Oleh karena itu, perusahaan diharuskan memiliki manajemen resiko yang baik dalam mengelola utangnya agar terhindar dari resiko kerugian yang seharusnya tidak patut terjadi.

3) Menderita kerugian

Tingginya laba bersih yang dimiliki sangat membantu perusahaan dalam melakukan reinvestasi, sehingga dapat menambah kekayaan bersih perusahaan meningkatkan return on equity dalam menjamin kepentingan investor. Dengan demikian, perusahaan dituntut untuk mampu meningkatkan nilai pendapatan dan mengendalikan tingkat biaya yang akan dikeluarkan. Bila suatu perusahaan tidak mampu untuk mempertahankan ketidakseimbangan nilai pendapatan dengan tingkat biaya yang dikeluarkan, maka perusahaan dapat mengalami kondisi financial distress di masa mendatang. 


\section{Dampak Financial Distress}

Kondisi kesulitan keuangan yang terjadi pada suatu perusahaan dapat memberikan dampak negatif, yakni perusahaan akan mengalami penciutan usaha, bahkan dalam kondisi kesulitan yang lebih bera $t$ dapat menyebabkan perusahaan tersebut ditutup atau dinyatakan bangkrut. Musthafa (2017: 200), menyatakan bahwa kondisi financial distress yang dialami oleh suatu perusahaan dapat dibagi menjadi dua golongan, yaitu kegagalan ekonomis (economic failure) dan kegagalan usaha (business failure).

1) Kegagalan ekonomis (economic failure)

Merupakan suatu kondisi dimana pendapatan yang diterima oleh perusahaan tidak memadai dalam menutup biaya operasional perusahaan. Bila hal ini terjadi secara terus-menerus, maka dapat dipastikan perusahaan akan mengalami kerugian operasional selama kurun waktu beberapa tahun.

2) Kegagalan usaha (business failure)

Merupakan suatu kondisi disaat perusahaan mengalami kegagalan, maka dapat menimbulkan kerugian bagi krediturnya, dikarenakan perusahaan tidak dapat membayarkan hutangnya.

\section{Makroekonomi}

Nilai tukar memiliki resiko ketidak pastian yang pasti akan dihadapi oleh seorang investor bila melakukan investasi di pasar global. Semakin tinggi fluktuasi dari nilai tukar, maka investor harus mempertimbangkan pula premi resiko atas nilai tukar tersebut (Rodoni dan Herni, 2014:196). Menurut Widarjo dan Setiawan (2009), depresiasi nilai tukar rupiah akan menyebabkan penurunan profitabilitas perusahaan. Dengan adanya penurunan ini memungkinkan perusahaan mengalami kondisi financial distress semakin besar. Pernyataan ini juga diperkuat oleh penelitian Endang dan Jumyetti (2017), tingkat fluktuasi nilai tukar sangat mempengaruhi perusahaan mengalami kondisi financial distress.

Suku bunga adalah salah satu variabel yang secara tidak langsung berpengaruh terhadap kondisi financial distress perusahaan (Djumahir, 2007). Suku bunga yang tinggi akan memperlemah kondisi perekonomian, karena saat suku bunga naik akan berpengaruh pada perhitungan bunga bagi kreditur dalam menentukan beban bunga. Selain itu, ketika suku bunga mengalami kenaikan, maka akan berdampak pada meningkatnya biaya modal dengan bentuk beban bunga yang akan ditanggung oleh perusahaan, sehingga laba yang diperoleh akan terpangkas. Dengan demikian, dapat diasumsikan bila suku bunga mengalami kenaikan akan memberikan dampak terjadinya kondisi financial distress bagi suatu perusahaan. Endang dan Jumyetti (2017) menyatakan bahwa faktor eksternal seperti inflasi, tingkat suku bunga dan fluktuasi nilai tukar akan membebani perusahaan, sehingga menyebabkan financial distress, sekalipun perusahaan tersebut adalah perusahaan besar dan listing di BEI. Pernyataan ini juga diperkuat oleh penelitian Kunt dan Detragiache (1997), menyatakan suku bunga memiliki pengaruh yang signifikan terhadap kondisi financial distress.

Teori suku bunga Fisher menyebutkan bahwa suku bunga atau tingkat bunga adalah hal yang penting diantara variabelvariabel makroekonomi. Tingkat bunga tersebut adalah harga yang menghubungkan masa kini dan masa depan. Terdapat dua tingkat suku bunga yaitu tingkat bunga riil dan nominal. Tingkat bunga riil adalah perbedaan diantara tingkat bunga nominal dan tingkat inflasi. Tingkat bunga dapat berubah karena dua alasan, yaitu karena tingkat bunga riil berubah atau tingkat inflasi berubah (Mankiw, 2000).

\section{Rerangka Konseptual Penelitian}

Gambar 1 menjelaskan pendekatan yang dapat dilakukan untuk mendeteksi kemungkinan terjadinya kondisi financial distress dalam suatu perusahan, yaitu dengan menganalisis variabel makro ekonomi suatu negara dan variabel mikro perusahaan yang diproksikan dengan rasio keuangan. Secara keseluruhan, rerangka konseptual dalam 
penelitian ini menjelaskan kemampuan variabel sensitivitas nilai tukar, sensitivitas suku bunga, current ratio, return on asset, total asset turnover, debt to asset ratio dan sales growth dalam memprediksi kondisi financial distress perusahaan.

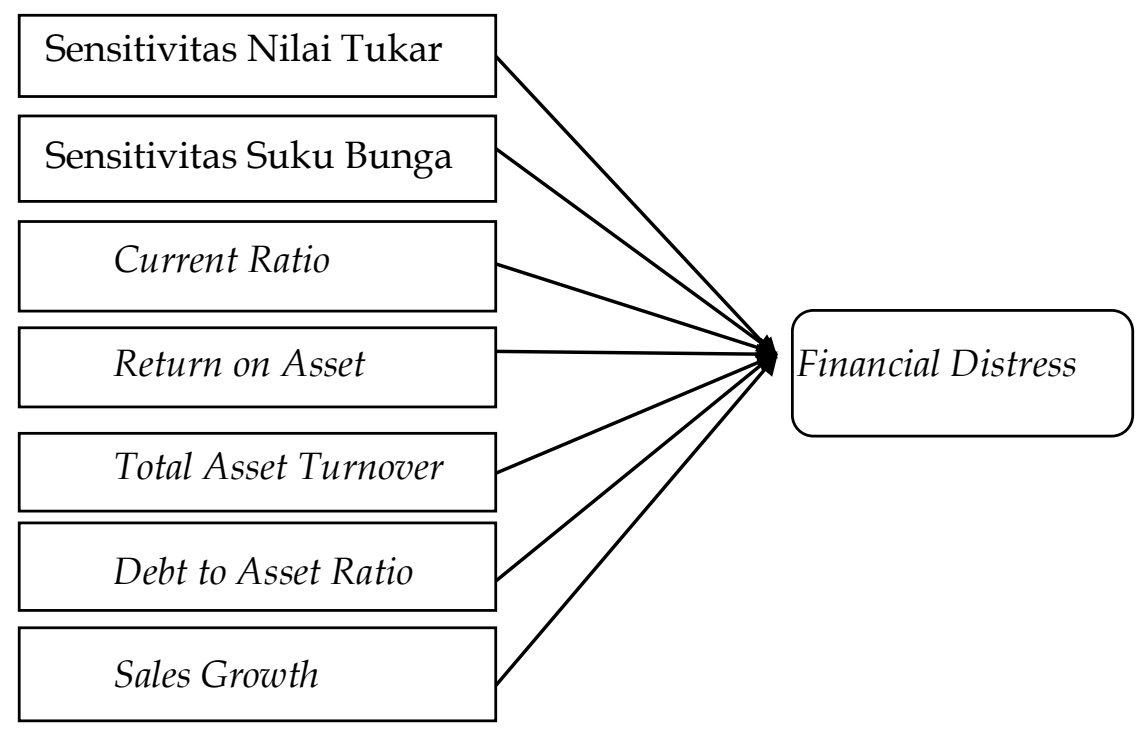

\section{Gambar 1 \\ Rerangka Konseptual Penelitian}

\section{Hipotesis}

Berdasarkan kajian teoritis, kajian empiris dan rerangka konseptual penelitian, maka dapat dirumuskan hipotesis sebagai berikut:

1) Nilai Tukar dan Financial Distress

Nilai tukar memiliki resiko ketidak pastian yang pasti akan dihadapi oleh seorang investor bila melakukan investasi di pasar global. Semakin tinggi fluktuasi dari nilai tukar, maka investor harus mempertimbangkan pula premi resiko atas nilai tukar tersebut (Rodoni dan Herni, 2014:196). Menurut Widarjo dan Setiawan (2009), depresiasi nilai tukar rupiah akan menyebabkan penurunan profitabilitas perusahaan. Dengan adanya penurunan ini memungkinkan perusahaan mengalami kondisi financial distress semakin besar. Pernyataan ini juga diperkuat oleh penelitian yang dilakukan oleh Endang dan Jumyetti (2017), tingkat fluktuasi nilai tukar sangat mempengaruhi perusahaan mengalami kondisi financial distress. Berdasarkan uraian tersebut, rumusan hipotesis penelitian yaitu:

$H_{1}$ : Nilai tukar dapat memprediksi kondisi financial distress.

2) Suku Bunga dan Financial Distress

Suku bunga adalah salah satu variabel yang secara tidak langsung berpengaruh terhadap kondisi financial distress perusahaan (Djumahir, 2007). Suku bunga yang tinggi akan memperlemah kondisi perekonomian, karena saat suku bunga naik akan berpengaruh pada perhitungan bunga bagi kreditur dalam menentukan beban bunga. Selain itu, ketika suku bunga mengalami kenaikan, maka akan berdampak pada meningkatnya biaya modal dengan bentuk beban bunga yang akan ditanggung oleh perusahaan, sehingga laba yang diperoleh akan terpangkas. Dengan demikian, dapat diasumsikan bila suku bunga mengalami kenaikan akan memberikan dampak terjadinya kondisi financial distress bagi suatu perusahaan. Endang dan Jumyetti (2107) menyatakan bahwa faktor ekster- 
nal seperti inflasi, tingkat suku bunga dan fluktuasi nilai tukar akan membebani perusahaan, sehingga menyebabkan financial distress, sekalipun perusahaan tersebut adalah perusahaan besar dan listing di BEI. Pernyataan ini juga diperkuat oleh penelitian yang dilakukan oleh Kunt dan Detragiache (1997), bahwa suku bunga memiliki pengaruh yang signifikan terhadap kondisi financial distress. Berdasarkan uraian tersebut, hipotesis penelitian yaitu :

$H_{2}$ : Suku bunga dapat memprediksi kondisi financial distress.

3) Current Ratio dan Financial Distress

Current ratio adalah rasio yang digunakan dalam mengukur kemampuan suatu perusahaan dalam memenuhi seluruh kewajiban yang segera jatuh tempo (Kasmir, 2008:134). Fadah (2013:42), mendefinisikan current ratio adalah rasio keuangan yang menggambarkan kemampuan perusahaan dalam melunasi utang yang harus segera dipenuhi dengan asset lancar. Nilai current ratio yang rendah mencerminkan bahwa perusahaan memiliki kekurangan modal dalam membayar utang, sementara itu, jika nilai current ratio yang diperoleh tinggi, dapat dipastikan perusahaan tersebut mampu memenuhi segala kebutuhan dalam kegiatan operasional perusahaan dan dapat menjaga kinerja perusahaan tersebut dengan baik. Hasil penelitian Nurhidayah dan Fitriyatur (2017), Antikasari dan Djuminah (2017) menjelaskan bahwa current ratio memiliki pengaruh yang signifikan dalam memprediksi financial distress perusahaan. Berdasarkan uraian tersebut, hipotesis yang dapat diambil yaitu:

$\mathrm{H}_{3}$ : Current ratio dapat memprediksi kondisi financial distress.

4) Return on Asset dan Financial Distress Menurut Gumanti (2011:115), return on asset adalah rasio keuangan yang digunakan untuk menunjukkan seberapa besar kemampuan perusahaan dalam menggunakan asset yang dimiliki untuk menghasilkan laba. Semakin tinggi return on asset, maka tercermin kemampuan perusahaan dalam mengelola asset yang dimiliki untuk memperoleh laba, sehingga kemungkinan untuk terjadi kondisi financial distress sangat rendah, begitu pula sebaliknya. Menurut Yap (2012), Antikasari dan Djuminah (2017) bahwa return on asset memiliki pengaruh negatif signifikan dan mampu dalam memprediksi financial distress. Berdasarkan uraian tersebut, hipotesis yang dapat diambil yaitu:

$H_{4}$ : Return on asset dapat memprediksi kondisi financial distress.

5) Total Asset Turnover dan Financial Distress Menurut Kasmir (2008:185), total asset turnover merupakan suatu rasio yang digunakan dalam mengukur perputaran seluruh asset yang dimiliki oleh perusahaan, serta digunakan juga untuk mengukur tingkat penjualan yang diperoleh. Nilai total asset turnover yang semakin tinggi menunjukkan kemampuan suatu perusahaan dalam mengelola asset, sehingga upaya untuk meningkatkan penjualan semakin tinggi, dan kemungkinan resiko terjadinya financial distress semakin rendah pula.

Menurut Yap (2012), bahwa total asset turnover memiliki pengaruh negatif dan mampu memprediksi kondisi financial distress, hal ini diperkuat dengan penelitian yang dilakukan Hanifah (2013), Antikasari dan Djuminah (2017) bahwa total asset turnover dapat digunakan untuk memprediksi kondisi financial distress perusahaan. Berdasarkan uraian tersebut, hipotesis yang dapat diambil yaitu :

$H_{5}$ : Total asset turnover dapat memprediksi kondisi financial distress

6) Debt to Asset Ratio dan Financial Distress Debt to asset ratio adalah rasio utang yang digunakan dalam mengukur seberapa besar asset perusahaan didanai oleh utang atau seberapa besar utang perusahaan memiliki pengaruh terhadap pengelolaan asset (Kasmir, 2008:156). Nilai Debt to asset ratio yang tinggi mengindikasikan bahwa sebagian besar 
asset yang dimiliki oleh perusahaan didanai dari utang. Oleh karena itu, hal ini akan menjadi pemicu terjadinya financial distress peusahaan.

Menurut Andre (2013), debt to asset ratio merupakan rasio yang digunakan untuk mengukur sejauh mana aktiva perusahaan dibiayai dengan utang. Apabila suatu perusahaan pembiayaannya lebih banyak menggunakan utang, makan akan berisiko terjadinya kesulitan pembayaran di masa yang akan datang. Jika keadaan ini tidak dapat diatasi dengan baik, potensi terjadinya financial distress. Kebangkrutan biasanya diawali dengan terjadinya moment gagal bayar. Perusahaan dengan banyak kreditor akan semakin cepat bergerak ke arah financial distress, dibanding perusahaan dengan kreditor tunggal.

Hasil penelitian Yap (2012), Moleong (2017), Antikasari dan Djuminah (2017) menunjukkan bahwa debt to asset ratio berpengaruh positif signifikan terhadap kondisi financial distress. Berdasarkan uraian tersebut, dirumuskan hipotesis penelitian, yaitu:

$H_{6}$ : Debt to asset ratio dapat memprediksi kondisi financial distress.

7) Sales Growth dan Financial Distress

Rasio pertumbuhan (sales growth) menggambarkan kemampuan perusahaan dalam meningkatkan penjualan dari periode waktu ke waktu dan digunakan juga dalam mengukur sejauh mana suatu perusahaan dalam mempertahankan posisi ekonominya (Widarjo dan Setiawan, 2009). Sales growth yang tinggi menunjukkan bahwa perusahaan tersebut berhasil menjalankan aktivitasnya, dengan demikian memperkecil kemungkinan perusahaan mengalami financial distress.

Hasil penelitian Raissa dan Mariana (2017) menjelaskan jika sales growth berpengaruh negatif signifikan terhadap kondisi financial distress. Pernyataan ini juga diperkuat oleh penelitian yang dilakukan Made dan Lely (2015) yang menyatakan bahwa sales growth mampu memengaruhi kondisi financial distress suatu perusahaan. Berdasarkan uraian tersebut, hipotesis yang dapat diambil yaitu:

$H_{7}$ : Sales growth dapat memprediksi kondisi financial distress.

\section{METODE PENELITIAN \\ Rancangan Penelitian}

Dengan mendasarkan pada tujuan penelitian, maka jenis penelitian yang digunakan adalah jenis penelitian explanatory research dengan menggunakan model regresi logistik.

\section{Populasi dan Sampel}

Populasi yang digunakan dalam penelitian ini adalah seluruh perusahaan sektor primer yang terdiri atas sektor pertanian dan sektor pertambangan yang terdaftar di Bursa Efek Indonesia (BEI) dan berjumlah sebanyak 42 perusahaan. Metode yang digunakan dalam penentuan sampel adalah purposive sampling. Jumlah perusahaan sektor primer yang memenuhi kriteria sampel sebanyak 39 perusahaan, dimana 9 perusahaan sektor pertanian dan 30 perusahaan sektor pertambangan dengan rentang waktu penelitian selama 10 tahun, mulai tahun 2008 - 2018.

\section{Metode Analisis Data}

Variabel Dependen

Variabel dependen yang digunakan dalam penelitian ini adalah financial distress. Financial distress dapat ditentukan dengan ketentuan sebagai berikut:

$\mathrm{Y}=1$, jika perusahaan sektor primer mengalami kondisi financial distress.

$Y=0$, jika perusahaan sektor primer tidak mengalami kondisi financial distress.

Variabel Independen

a) Nilai Tukar

Data yang digunakan dalam penelitian ini berupa nilai tukar bulanan, yakni nilai tukar bulan ini dikurangi dengan nilai tukar bulan sebelumya dan dibagi dengan nilai 
tukar bulan sebelumnya selama periode penelitian. Pengukuran variabel nilai tukar yang dipoksikan dengan sensitivitas nilai tukar merujuk pada penelitian yang dilakukan oleh Luciana (2004) dimana sensitivitas perusahaan diukur dengan menggunakan persamaan regresi linier sederhana return saham perusahaan yang diberi simbol $\left(Y_{R S}\right)$ terhadap nilai tukar. Akan tetapi, dalam penelitian ini, return saham perusahaan diberi simbol $(Z)$ agar memiliki perbedaan dengan simbol $Y$ pada kategori financial distress. Djumahir (2007) dan Sulaksana (2016) yang juga menggunakan return saham sebagai variabel dependen dalam mencari sensitivitas nilai tukar perusahaan. Formulasi adalah sebagai berikut:

$$
\mathrm{Z}=\mathrm{a}+\mathrm{b}_{\mathrm{it}} \mathrm{Nilai} \text { Tukar }+\mathrm{e}_{\mathrm{t}}
$$

b) Suku Bunga

Suku bunga yang digunakan dalam penelitian ini adalah tingkat suku bunga acuan atau BI Rate. Data yang digunakan dalam penelitian ini adalah data BI Rate bulanan, yakni suku bunga periode saat ini dikurangi dengan suku bunga periode sebelumnya dan dibagi dengan suku bunga periode sebelumnya selama periode penelitian. Penelitian ini menerapkan pendekatan sensitivitas suku bunga BI Rate. Pengukuran variabel suku bunga merujuk pada penelitian yang dilakukan oleh Luciana (2004), Djumahir (2007) dan Sulaksana (2016). Formulasi dalam mengukur sensitivitas suku bunga adalah sebagai berikut:

$$
\mathrm{Z}=\mathrm{a}+b_{i} \text { Suku Bunga }+e_{t}
$$

\section{c) Current Ratio}

Proses penghitungan current ratio dapat dilakukan dengan cara membandingkan total asset lancar dengan total utang lancar. Rasio ini dirumuskan sebagai berikut (Kasmir, 2008:134):

Current Ratio $=\frac{\text { Asset Lancar (Current Assets) }}{\text { Utang Lancar (Current Liabilities) }} \times 100 \%$

d) Return on Asset
Proses penghitungan return on asset dapat dilakukan dengan cara membandingkan laba bersih dengan total asset. Rasio ini dirumuskan sebagai berikut (Farah, 2014:18):

$$
\begin{gathered}
\text { Return on Asset }= \\
\frac{\text { Laba Bersih setelah pajak (Earning After Tax) }}{\text { Total Aset (Total Assets) }} \times 100 \%
\end{gathered}
$$

\section{e) Total Asset Turnover}

Proses penghitungan total asset turnover dapat dilakukan dengan cara membandingkan jumlah penjualan dengan total asset yang dimiliki. Rasio ini dirumuskan sebagai berikut (Kasmir, 2008:186):

Total Asset Turnover $=\frac{\text { Penjualan }(\text { Sales })}{\text { Total Aset }(\text { Total Assets })} \times 100 \%$

\section{f) Debt to Asset Ratio}

Proses penghitungan debt to asset ratio dapat dilakukan dengan cara membandingkan total utang dengan total asset yang dimiliki. Rasio ini dirumuskan sebagai berikut (Kasmir, 2008:156):

Debt to Asset Ratio $=\frac{\text { Total Utang }(\text { Total Debt })}{\text { Total Aset }(\text { Total Assets })} \times 100 \%$

\section{g) Sales Growth}

Proses penghitungan sales growth dapat dilakukan dengan menghitung selisih penjualan saat ini dengan penjualan sebelumnya, kemudian dibagi dengan penjualan sebelumnya. Rasio ini dirumuskan sebagai berikut (Made dan Lely, 2015):

Sales Growth $=\frac{\text { Salest }_{\mathrm{t}} \text { Sales }_{\mathrm{t}-1}}{\text { Sales }_{\mathrm{t}-1}} \times 100 \%$

\section{Model Analisis Regresi Logistik}

Model analisis yang digunakan dalam penelitian ini adalah analisis regresi logistik. Analisis ini digunakan apabila data variabel dependennya berupa data dikotomi. Data dikotomi merupakan data nominal dimana terdapat dua kategori, seperti sehat atau tidak sehat. Nilai dikotomi biasanya dinyatakan dalam bentuk angka 0 atau 1 (Fridayana, 2013:55). Karena variabel dependen $(\mathrm{Y})$ dalam penelitian ini memiliki skala nominal, maka dapat digunakan formulasi model regresi logistik sebagai berikut: 
$Y=\ln \left(\frac{P}{1-P}\right)=a+b_{1} X_{1}+b_{2} X_{2}+b_{3} X_{3}+b_{4} X+$ $b_{5} x_{5}+b_{6} x_{6}+b_{7} x_{7}+e$

\section{Keterangan:}

$\ln \left(\frac{\mathrm{P}}{1-\mathrm{P}}\right): \log$ dari perbandingan antara peluang financial distress dan peluang non financial distress.

$a$ : Konstanta; $b_{1}-b_{7}$ : Koefisien regresi variabel independen; $X_{1}$ : sensitivitas nilai tukar; $\mathrm{X}_{2}$ : Sensitivitas suku bunga; $\mathrm{X}_{3}$ :Current Ratio; $\mathrm{X}_{4}$ : Return on Asset; $\mathrm{X}_{5}$ : Total Asset Turnover; $\mathrm{X}_{6}$ : Debt to Asset Ratio; $\mathrm{X}_{7}$ : Sales Growth; e : Eror atau tingkat kesalahan yang mungkin terjadi.

\section{Uji Kelayakan Model Regresi Logistik (Menilai Model Fit)}

Menurut Ghozali (2016), uji kelayakan model harus diterapkan pada model regresi logistik, karena apabila terdapat data yang tidak layak dapat memberikan hasil atau kesimpulan yang rancu terhadap data hasil observasi. Uji kelayakan dilakukan guna mengetahui apakah model statistik telah layak digunakan atau tidak. Jika masih terdapat masalah pada uji kelayakan ini, maka dapat dilakukan proses seleksi ulang terhadap variabel yang digunakan. Beberapa uji statistik yang dapat digunakan dalam menilai model fit analisis regresi logistik, meliputi:

a) -2 Log Likelihood

Output yang dihasilkan dari SPSS mendapatkan dua nilai -2 Log Likelihood yakni, satu model atau block 0 untuk memasukkan konstanta dan kedua model atau block 1 dengan konstanta dan variabel independen. Statistik -2 Log Likelihood dapat dijadikan sebagai penentu bila variabel independen ditambahkan ke dalam model berpengaruh secara signifikan atau tidak dalam memperbaiki model fit. Bila nilai -2 Log Likelihood mengalami penurunan, maka hal tersebut menunjukkan bahwa model yang dihipotesiskan telahfit dengan data (Sofyan dan Heri, 2014:105). b) Cox and Snell's $R$ Square dan Nagelkerke $R$ Square

Menurut Sofyan dan Heri (2014:99), Cox and Snell's $R$ Square merupakan suatu ukuran yang digunakan untuk membandingkan nilai -2 Log Likelihood dengan skala maksimumnya adalah 1 . Sementara itu, Nagelkerke R Square merupakan suatu bentuk pengujian yang dilakukan guna mengetahui seberapa besar variabel independen mampu menjelaskan variabel dependennya. Uji ini merupakan bentuk penyesuaian dari model Cox and Snell's $R$ Square dan skalanya dipersempit menjadi keseluruhan nilai antara 0 dan 1 . Nilai dari Nagelkerke $R$ Square digunakan untuk mengetahui persentase variabilitas dari variabel dependen yang dapat dijelaskan oleh variabel independen di dalam penelitian.

c) Hosmer and Lemeshow's Goodness of Fit Test Uji statistik ini digunakan untuk menguji apakah nilai yang akan digunakan sesuai dengan data empiris (Soyan dan Heri, 2014:100). Jika nilai yang diperoleh dari Hosmer and Lemeshow's Goodness of Fit Test sama dengan atau kurang dari 5\%, dapat disimpulkan bahwa hipotesis nol ditolak, sehingga bermakna bahwa terdapat perbedaan yang signifikan antara model dengan nilai observasinya, serta uji hipotesis tidak dapat dilanjutkan pada tahap selanjutnya, sedangkan bila nilai dari Hosmer and Lemeshow's Goodness of Fit Test lebih dari 5\%, maka dapat disimpulkan bahwa hipotesis nol diterima dan bermakna bahwa model layak digunakan pada analisis selanjutnya (Darmawan, 2017).

d) Tabel Klasifikasi $2 \times 2$

Menurut Sofyan dan Heri (2014:106), tabel ini digunakan untuk membandingkan nilai estimasi yang benar dan salah. Terdapat kolom yang berisi dua nilai prediksi dari variabel dependen yang diteliti, sementara itu juga terdapat baris yang menunjukkan nilai variasi yang sesungguhnya dari variabel dependen. 
Ketika model yang diperoleh sempurna, seluruh kasus akan berada pada diagonal dengan tingkat ketepatan prediksi yang mencapai $100 \%$.

\section{Uji Hipotesis}

Setelah diperoleh model yang telah fit terhadap data, langkah selanjutnya adalah melakukan uji hipotesis. Menurut Riza (2018), uji ini dilakukan untuk menguji apakah secara parsial variabel independen dapat menjelaskan variabel dependen dengan baik. Adapun langkah-langkah yang perlu diperlukan dalam uji hipotesis ini adalah sebagai berikut:

a) Merumuskan hipotesis

b) Menentukan tingkat signifikansi (a)

Pengujian tingkat signifikansi yang dilakukan dalam penelitian ini adalah pengujian secara parsial (individual). Oleh karena itu, uji ini dilakukan dengan menggunakan uji Wald pada tahap selanjutnya dengan menggunakan tingkat signifikansi $1 \%$, 5\% dan $10 \%$.

c) Uji Wald

Menurut Sofyan dan Heri (2014:106), statistik uji Wald digunakan sebagai uji parsial (individual) atas variabel-variabel yang digunakan. Uji ini dilakukan untuk melihat seberapa besar pengaruh koefisien variabel independen secara parsial terhadap variabel dependen. Kriteria pengambilan keputusan, yaitu:

1) Jika nilai $p$-value uji Wald (Sig) $>a$, maka $H_{0}$ diterima, yang bermakna variabel independen secara parsial tidak berpengaruh terhadap kondisi financial distress perusahaan.

2) Jika nilai $p$-value uji Wald (Sig) $\leq a$, maka $H_{0}$ ditolak, yang bermakna variabel independen secara parsial berpengaruh terhadap kondisi financial distress perusahaan.

d) Menarik kesimpulan

\section{ANALISIS DAN PEMBAHASAN \\ Deskriptif Statistik Data}

Analisis deskriptif statistik data dilakukan untuk memperoleh gambaran umum terkait data penelitian yang mencakup nilai minimum, maksimum, rata-rata dan standar deviasi. Hasil deskriptif statistik data variabel penelitian disajikan pada Tabel 1 berikut:

Tabel 1

Hasil Deskriptif Statistik Sektor Primer Tahun 2008-2018 (n=390)

\begin{tabular}{lcccc}
\hline \multicolumn{1}{c}{ Variabel } & Maksimum & Minimum & Rata-rata & $\begin{array}{c}\text { Deviasi } \\
\text { Standar }\end{array}$ \\
\hline Sensitivitas nilai tukar (\%) & 7,289 & $-9,655$ & $-1,181$ & 1,069 \\
Sensitivitas suku bunga (\%) & 23,451 & $-22,679$ & $-0,324$ & 1,553 \\
Current Ratio (\%) & 25,594 & 0,021 & 2,267 & 0,914 \\
Return On Asset (\%) & 0,839 & $-3,198$ & 0,026 & 0,133 \\
Total Asset Turnover (\%) & 5,328 & $-0,088$ & 0,696 & 0,113 \\
Debt to Asset Ratio (\%) & 6,270 & 0,063 & 0,612 & 0,368 \\
Sales Growth (\%) & 9,743 & $-13,794$ & 0,167 & 0,767 \\
\hline
\end{tabular}

Sumber: Data diolah, 2019

Tabel 1 menunjukkan nilai maksimum variabel sensitivitas nilai tukar dimiliki perusahaan dengan kode emiten CITA dan nilai minimum berada pada perusahaan dengan kode emiten PKPK. Nilai deviasi standar yang lebih tinggi dari nilai rata-rata mengindasikan variabilitas data yang se- makin besar. Selain itu nilai maksimum dari variabel sensitivitas suku bunga dimiliki perusahaan dengan kode emiten DSFI dan nilai minimum berada pada perusahaan dengan kode emiten ATPK. Nilai deviasi standar yang tinggi dari nilai rata-rata mengindikasikan bahwa variabilitas data 
sensitivitas suku bunga semakin besar. Tingkat sensitivitas suku bunga yang tinggi dapat memperlemah kondisi keuangan perusahaan, sebab dapat meningkatkan biaya modal dalam bentuk beban bunga dan berdampak pada terpangkasnya laba yang diperoleh.

Current ratio (CR) digunakan untuk mengukur kemampuan perusahaan dalam memenuhi seluruh kewajiban jangka pendeknya. Semakin tinggi nilai current ratio (CR) semakin baik bagi perusahaan. Nilai maksimum dari variabel current ratio (CR) dimiliki perusahaan dengan kode emiten ADRO, dan nilai minimum berada pada perusahaan dengan kode emiten INDY. Nilai deviasi standar yang rendah dari nilai ratarata mengindikasikan bahwa variabilitas data yang digunakan semakin kecil.

Return on assets (ROA) adalah salah satu rasio profitabilitas yang menjelaskan kemampuan perusahaan dalam menggunakan asset yang dimiliki untuk memperoleh laba. Semakin tinggi nilai return on assets (ROA), semakin baik bagi perusahaan. Nilai maksimum yang didapat dari variabel return on assets (ROA) dimiliki perusahaan dengan kode emiten DEWA, sedangkan nilai minimum berada pada perusahaan dengan kode emiten CKRA. Nilai deviasi standarnya lebih tinggi dari nilai rata-rata, sehingga dapat dikatakan variabilitas data yang digunakan semakin besar.

Total asset turnover (TATO) adalah rasio yang digunakan untuk mengukur perputaran seluruh asset yang dimiliki oleh perusahaan. Semakin tinggi nilai dari variabel total asset turnover (TATO) menunjukkan kemampuan perusahaan dalam mengelola asset yang dimiliki semakin baik. Nilai maksimum yang diperoleh dari variabel total asset turnover (TATO) dimiliki perusahaan dengan kode emiten PKPK, sedangkan nilai minimum berada pada perusahaan dengan kode emiten DKFT. Nilai deviasi standar tersebut nilainya lebih rendah dari nilai rataratanya, sehingga dapat dikatakan bahwa variabilitas data yang digunakan semakin kecil. Debt to asset ratio (DAR) merupakan salah satu rasio solvabilitas yang digunakan untuk mengukur perbandingan total utang dengan total asset yang dimiliki oleh perusahaan yaitu seberapa besar asset perusahaan didanai oleh utang. Nilai debt to asset ratio (DAR) yang tinggi mencerminkan bahwa sebagian besar asset yang dimiliki oleh perusahaan didanai oleh utang, hal ini akan semakin menambah beban perusahaan dalam menutupi kewajiban serta bunga yang dibebankan. Nilai maksimum yang diperoleh variabel debt to asset ratio (DAR) dimiliki perusahaan dengan kode emiten BYAN, sedangkan nilai minimum berada pada perusahaan dengan kode emiten RUIS. Nilai deviasi standar lebih rendah dari nilai rata-ratanya, sehingga dapat diasumsikan variabilitas data yang digunakan lebih kecil.

Sales growth (SG) merupakan rasio yang menggambarkan kemampuan suatu perusahaan dalam meningkatkan penjualan dari periode waktu ke waktu dan digunakan juga dalam mengukur sejauh mana suatu perusahaan dalam mempertahankan posisi ekonominya. Semakin tinggi nilai dari variabel sales growth, maka dapat dikatakan kinerja perusahaan dalam meningkatkan penjualan semakin baik. Nilai maksimum dari variabel sales growth (SG) dimiliki perusahaan dengan kode emiten GEMS, sedangkan nilai minimumnya berada pada perusahaan dengan kode emiten DSFI. Nilai deviasi standar yang diperoleh lebih tinggi dari nilai rata-ratanya, sehingga dapat dikatakan bahwa variabilitas dari data yang digunakan semakin besar pula.

\section{Hasil Analisis Regresi Logistik}

Pengujian analisis regresi logistik dilakukan guna mengetahui sejauh mana kemampuan variabel independen yang terdiri dari nilai tukar, suku bunga, current ratio, return on asset, total asset turnover, debt to asset ratio dan sales growth dalam memprediksi variabel dependennya, yaitu financial distress. Hasil dari uji regresi logistik disajikan dalam Tabel 2 sebagai berikut: 
Tabel 2

Hasil Uji Analisis Regresi Logistik

\begin{tabular}{lccll}
\hline \multicolumn{1}{c}{ Variabel } & $\begin{array}{c}\text { Koef. } \\
\text { Regresi }\end{array}$ & Wald & $\begin{array}{c}\text { Tingkat } \\
\text { Signifikansi }\end{array}$ & Keterangan \\
\hline Konstanta & $-0,069$ & 0,149 & 0,669 & - \\
Sensitivitas nilai tukar & $-0,035$ & 0,058 & 0,269 & Tidak Signifikan \\
Sensitivitas suku bunga & $-0,020$ & 0,122 & 0,727 & Tidak Signifikan \\
Current Ratio & 0,023 & 1,027 & 0,311 & Tidak Signifikan \\
Return On Asset & $-6,894$ & 25,400 & 0,000 & Signifikan \\
Total Asset Turnover & $-0,193$ & 2,385 & 0,122 & Tidak Signifikan \\
Debt to Asset Ratio & 0,476 & 4,263 & 0,039 & Signifikan \\
Sales Growth & 0,086 & 0,149 & 0,474 & Tidak Signifikan \\
\hline
\end{tabular}

Sumber: Data diolah, 2019

Keterangan: Signifikan pada $a=5 \%$;

Berdasarkan hasil uji analisis regresi logistik pada Tabel 2, maka diperoleh persamaan regresi logistik sebagai berikut:

$$
\begin{aligned}
\mathrm{Y}=\ln \left(\frac{\mathrm{P}}{1-\mathrm{P}}\right)= & -0,069-0,035 \text { Sensitivitas nilai } \\
& \text { tukar }-0,020 \text { Sensitivitas suku } \\
& \text { bunga }+0,023 \mathrm{CR}-6,894 \mathrm{ROA}- \\
& \text { 0,913TATO }+ \text { 0,476DAR }+ \\
& 0,086 \mathrm{SG}+\mathrm{e}
\end{aligned}
$$

Uji Kelayakan Regresi Logistik (Model Fit)

Hasil pengujian keseluruhan model fit dapat diuraikan sebagai berikut:

a) -2 Log Likelihood

Hasil pengujian -2 Log Likelihood dapat dilihat pada Tabel 3 berikut:

Tabel 3, menunjukkan bahwa nilai -2 Log Likelihood sebesar 540,398 -dan ketika variabel independen telah dimasukkan dalam model pada block, nilai -2 Log Likelihood turun menjadi 475,031 Terjadinya penurunan nilai -2 Log Likelihood sebesar 65,367 -ini mengindikasikan bahwa model uji regresi logistik yang dihasilkan setelah ditambahkan variabel independen ke dalam model menjadi lebih baik dan model dinyatakan fit dengan data.

\section{Tabel 3}

Hasil Pengujian -2 Log Likelihood

\begin{tabular}{cc}
\hline Keterangan & Nilai Statistik \\
\hline -2 Log Likelihood (Block 0) & 540,398 \\
$-2 \log$ Likelihood (Block 1) & 475,031 \\
\hline
\end{tabular}

Sumber: diolah, 2019 b) Cox and Snell's R Square dan Nagelkerke $R$ Square

Hasil pengujian Cox and Snell's $R$ Square dan Nagelkerke $R$ Square ditunjukkan pada Tabel 4.

Tabel 4

Pengujian Cox and Snell's R Square dan Nagelkerke R Square

\begin{tabular}{lc}
\hline \hline \multicolumn{1}{c}{ Keterangan } & $\begin{array}{c}\text { Nilai } \\
\text { Statistik }\end{array}$ \\
\hline Uji -2 Log Likelihood & 475,031 \\
Uji Cox and Snell's R & \\
Square & 0,154 \\
Uji Nagelkerke R Square & 0,206 \\
\hline Sumber: diolah, 2019
\end{tabular}

Berdasarkan Tabel 4, diperoleh nilai uji Cox and Snell's R Square sebesar 0,154 dan nilai uji Nagelkerke R Square sebesar 0,206. Hal ini mengindikasikan bahwa variabilitas variabel dependen yaitu financial distress yang dapat dijelaskan oleh variabilitas variabel independen yang terdiri dari sensitivitas nilai tukar, sensitivitas suku bunga, current ratio, return on asset, total asset turnover, debt to asset ratio dan sales growth sebesar 20,6\%. Sedangkan sisanya sebesar $79,4 \%$ dijelaskan oleh variabel lain yang tidak dimasukkan ke dalam model uji regresi logistik.

c) Hosmer and Lemeshow's Goodness of Fit Test 
Hasil pengujian Hosmer and Lemeshow's Goodness of Fit Test ditunjukkan pada Tabel 5.

Tabel 5

Hasil Pengujian Hosmer and Lemeshow's Goodness of Fit Test

\begin{tabular}{lc}
\hline \hline \multicolumn{1}{c}{ Keterangan } & Nilai Statistik \\
\hline Chi-Square & 14,818 \\
Signifikansi Value & 0,063 \\
\hline Sumber: diolah, 2019 &
\end{tabular}

Berdasarkan Tabel 5, nilai goodness of fit test yang diukur dengan menggunakan nilai chi-square menunjukkan nilai sebesar 14,818 dengan signifikansi value 0,063 atau $6,3 \%$, dimana lebih besar dari 0,05 atau $5 \%$. Hal ini mengindikasikan bahwa tidak terdapat perbedaan antara model dengan data yang diobservasi, sehingga model telah dikatakan fit dengan data dan dapat diterima. d) Uji Klasifikasi $2 \times 2$

Hasil pengujian tabel klasifikasi $2 \times 2$ ditunjukkan pada Tabel 6. Tabel 6, menunjukkan bahwa persamaan uji regresi logistik yang telah terbentuk dapat membuat klasifikasi dalam penaksiran nilai variabel dependen sebesar $69,7 \%$, yang mengindikasikan bahwa model persamaan regresi logistik ini dapat digunakan untuk memprediksi perusahaan mengalami kondisi financial distress, begitu pula sebaliknya. Menurut Ghozali (2016), ketepatan suatu prediksi dari model prediksi yang diperoleh dapat dikatakan baik jika nilai ketepatan lebih dari 50\%.

Jadi, berdasarkan keempat bentuk uji statistik yang dilakukan untuk menilai kelayakan dari uji regresi logistik atau model fit, diperoleh hasil yang konsisten menunjukkan bahwa model uji regresi logistik yang digunakan telah fit dengan data penelitian, serta mampu digunakan untuk memprediksi nilai observasinya.

Tabel 6

Hasil Uji Klasifikasi 2 × 2

\begin{tabular}{lccc}
\hline \hline \multirow{2}{*}{ Keterangan } & \multicolumn{3}{c}{ Prediksi } \\
\cline { 2 - 4 } & $\begin{array}{c}\text { Non Financial } \\
\text { Distress }\end{array}$ & $\begin{array}{c}\text { Financial } \\
\text { Distress }\end{array}$ & $\begin{array}{c}\text { Ketepatan } \\
\text { Klasifikasi }\end{array}$ \\
\hline Non Financial Distress & 147 & 53 & $73,5 \%$ \\
Financial Distress & 65 & 125 & $65,8 \%$ \\
Persentase Keseluruhan (\%) & & & $69,7 \%$ \\
\hline
\end{tabular}

Sumber: diolah, 2019

\section{Hasil Pengujian Hipotesis Penelitian}

Berdasarkan Tabel 2, menunjukkan bahwa sensitivitas nilai tukar, sensitivitas suku bunga, current ratio, total asset turnover dan sales growth tidak dapat digunakan untuk memprediksi kondisi financial distress, artinya hipotesis ditolak $\left(\mathrm{H}_{0}\right.$ diterima), maksudnya variabel independen tersebut tidak dapat menentukan perusahaan mengalami kondisi financial distress atau tidak (Hipotesis ditolak). Terbukti variabel-variabel tersebut memiliki $p$-value uji Wald (Sig.) > a, dimana a sebesar 5\%. Namun, return on asset dan debt to asset ratio dapat digunakan untuk memprediksi kondisi financial distress, artinya hipotesis diterima $\left(\mathrm{H}_{0}\right.$ ditolak), maksudnya variabel independen tersebut dapat menentukan perusahaan mengalami kondisi financial distress atau tidak (Hipotesis diterima). Terbukti variabel independen tersebut memiliki $p$-value uji Wald (Sig) $<a$, dengan a sebesar $5 \%$.

\section{Pembahasan \\ Prediksi Sensitivitas Nilai Tukar Terhadap Financial Distress}

Berdasarkan hasil pengujian regresi logistik, tidak menemukan nilai tukar yang 
diproksikan dengan sensitivitas nilai tukar mampu memprediksi kondisi financial distress perusahaan, dimana hal ini ditunjukkan dengan tingkat signifikansi 0,269 atau 26,9\% lebih besar dari tingkat signifikansi yang telah ditentukan, yakni sebesar 5\%, sehingga hasil penelitian ini tidak dapat membuktikan hipotesis.

Tingkat sensitivitas nilai tukar memberikan indikasi penilaian investor terhadap tingkat keuntungan potensial yang akan diperoleh perusahaan di masa mendatang. Semakin tinggi tingkat sensitivitas nilai tukar yang diperoleh perusahaan mengindikasikan bahwa perusahaan semakin sensitif terhadap kondisi perekonomian. Interpretasi dari hasil uji tersebut menunjukkan bahwa tingkat sensitivitas nilai tukar tidak dapat memengaruhi kondisi financial distress perusahaan. Hal ini dapat terlihat dari hasil ratarata nilai sensitivitas nilai tukar yang cenderung menurun selama periode penelitian, sehingga dapat diasumsikan bahwa kondisi ekonomi masih relatif terjaga kestabilannya dan tidak berpengaruh besar terhadap return saham yang nantinya berdampak pada kinerja keuangan perusahaan. Namun hasil ini tidak dapat dijadikan sebagai acuan dikarenakan faktor nilai tukar yang cenderung befluktuasi di setiap beberapa periode waktu.

Hasil penelitian ini sesuai dengan penelitian yang dilakukan oleh Sulaksana (2016), Nurhidayah dan Fitriyatur (2017) dan Darmawan (2017) yang menyatakan bahwa nilai tukar tidak berpengaruh signifikan terhadap kondisi financial distress perusahaan. Namun berbanding terbalik dengan penelitian yang dilakukan oleh Endang dan Jumyetti (2017) yang menyatakan bahwa nilai tukar memiliki pengaruh yang signifikan terhadap kondisi financial distress perusahaan.

\section{Prediksi Sensitivitas Suku Bunga Terhadap Financial Distress}

Berdasarkan hasil pengujian regresi logistik, menunjukkan bahwa suku bunga yang diproksikan dengan sensitivitas suku bunga tidak mampu memprediksi kondisi financial distress perusahaan sektor primer. Suku bunga yang diproksikan dengan sensitivitas suku bunga memiliki hubungan negatif dan tidak signifikan terhadap kondisi financial distress yang dialami oleh perusahaan dan ditunjukkan dengan tingkat signifikansi 0,727, dimana lebih besar dari tingkat signfikansi yang telah ditentukan, yakni sebesar 5\%, sehingga dapat disimpulkan bahwa hasil penelitian ini tidak dapat membuktikan hipotesis.

Interpretasi dari hasil uji tersebut dapat menunjukkan bahwa tingkat sensitivitas suku bunga tidak dapat dijadikan sebagai variabel penentu terjadinya kondisi financial distress perusahaan. Hal ini dapat terlihat dari nilai rata-rata keseluruhan yang diperoleh dari sensitivitas suku bunga yang sangat rendah selama periode penelitian, sehingga dapat diasumsikan bahwa bila tingkat sensitivitas suku bunga yang diperoleh oleh perusahaan rendah, maka tidak akan memengaruhi performa kinerja keuangan perusahaan. Menurut Sapoerti (2013) bahwa suku bunga berpengaruh signifikan terhadan financial distress, dikarenakan perusahaan cenderung memilih menggunakan modal sendiri daripada menggunakan modal dari luar.

Hasil penelitian ini mendukung penelitian Veronika dan Anantadjaya (2006), Djumahir (2007), Alifiah (2014) dan Darmawan (2017) yang menyatakan bahwa suku bunga (sensitivitas suku bunga) berpengaruh negatif tidak signifikan terhadap kondisi financial distress perusahaan. Penelitian Moleong (2017) juga menegaskan real interest rate berpengaruh tidak signifikan terhadap financial distress.

\section{Prediksi Current Ratio Terhadap Financial Distress}

Berdasarkan hasil pengujian regresi logistik, ditemukan bahwa variabel current ratio tidak mampu memprediksi kondisi financial distress. Hasil ini ditunjukkan dengan tingkat signifikansi sebesar 0,311 dimana lebih besar dari tingkat signifikansi 
yang telah ditentukan, yakni sebesar 5\%, sehingga dapat dikatakan bahwa hasil ini tidak dapat membuktikan hipotesis.

Pengaruh positif dan tidak signifikan tersebut disebabkan ketika perusahaan yang memiliki nilai current ratio diatas kisaran rata-rata akan tetapi perusahaan tersebut tidak dapat mengelola asset lancarnya secara produktif, dikarenakan jumlah dari asset lancar yang terlalu besar, sehingga perusahaan akan kehilangan kesempatan untuk meraih keuntungan. Selain itu, pengaruh tidak signifikan ini juga bisa disebabkan oleh kegiatan operasional perusahaan sektor primer yang cenderung masih tergolong musiman.

Hasil penelitian ini konsisten dengan penelitian Widarjo dan Setiawan (2009) bahwa variabel current ratio memiliki pengaruh tidak signifikan terhadap financial distress yang dialami oleh suatu perusahaan. Namun, tidak konsisten dengan penelitian Nurhidayah dan Fitriyatur (2017), Antikasari dan Djuminah (2017).

\section{Prediksi Return on Asset Terhadap Finan- cial Distress}

Berdasarkan hasil pengujian regresi logistik, ditemukan bahwa return on asset yang merupakan proksi dari variabel profitabilitas mampu memprediksi secara signifikan dan arah negatif terhadap kondisi financial distress yang dialami oleh perusahaan dan ditunjukkan dengan tingkat signifikansi 0,000 yang lebih kecil dari tingkat signifikansi yang ditentukan, yakni sebesar $5 \%$, sehingga hasil ini dapat membuktikan hipotesis yang dibuat.

Interpretasi dari hasil pengujian tersebut dapat dilihat selama periode penelitian, perusahaan sektor primer memiliki rata-rata tingkat profitabilitas sebesar 2,6\% dimana mengindikasikan bahwa perusahaan sektor primer tetap mendapatkan keuntungan pasca terjadinya krisis keuangan global walaupun tingkat profitabilitasnya masih dalam angka yang relatif rendah. Dengan menggunakan asumsi bahwa besarnya laba yang diperoleh, maka akan membuat per- usahaan lebih mudah melakukan berbagai kegiatan ekspansi, sehingga menjauhkan perusahaan dari kondisi krisis atau financial distress.

Hasil penelitian ini konsisten dengan penelitian Yap (2012), Hanifah (2013), Antikasari dan Djuminah (2017) bahwa return on asset memiliki pengaruh negatif dan signifikan terhadap kondisi financial distress perusahaan.

\section{Prediksi Total Asset Turnover Terhadap Financial Distress}

Berdasarkan hasil pengujian regresi logistik, ditemukan bahwa total asset turnover tidak mampu memprediksi kondisi financial distress perusahaan dan memiliki hubungan negatif. Hasil ini ditunjukkan dengan tingkat signifikansi 0,122 yang lebih besar dari tingkat signifikansi yang diisyaratkan, yakni sebesar 5\%, sehingga hasil ini tidak dapat membuktikan hipotesis.

Interpretasi dari hasil pengujian tersebut dapat menunjukkan bahwa nilai dari total asset turnover tidak dapat dijadikan sebagai variabel penentu terjadinya kondisi financial distress perusahaan dengan korelasi negatif. Hal ini dapat terlihat dari nilai rata-rata keseluruhan yang diperoleh dari variabel total asset turnover yang sangat rendah selama periode penelitian, sehingga dapat diasumsikan bahwa bila tingkat total asset turnover yang diperoleh oleh perusahaan tinggi, maka akan menghindarkan perusahaan untuk mengalami kondisi financial distress. Akan tetapi, secara keseluruhan, kondisi financial distress perusahaan tidak hanya disebabkan oleh tingkat penjualan yang menurun, melainkan juga terdapat aspekaspek lain yang memengaruhi, seperti terjadinya peningkatan kewajiban perusahaan, baik kewajiban jangka pendek maupun jangka panjang.

Hasil penelitian ini mendukung penelitian yang telah dilakukan oleh Yulpa (2017) yang menyatakan bahwa total asset turnover memiliki pengaruh tidak signifikan terhadap kondisi financial distress perusahaan. Namun, tidak konsisten dengan hasil 
penelitian Antikasari dan Djuminah (2017), bahwa total asset turnover berpengaruh negatif signifikan terhadap financial distress.

\section{Prediksi Debt to Asset Ratio Terhadap Financial Distress.}

Berdasarkan hasil pengujian regresi logistik, ditemukan bahwa debt to asset ratio mampu memprediksi secara signifikan dan arah positif kondisi financial distress yang dialami oleh perusahaan dan ditunjukkan dengan tingkat signifikansi 0,039 yang lebih kecil dari tingkat signifikansi yang ditentukan, yakni sebesar 5\%, sehingga hasil ini dapat membuktikan hipotesis. Pengaruh positif signifikan tersebut dapat dibuktikan berdasarkan nilai rata-rata debt to asset ratio secara keseluruhan yang diperoleh dari perusahaan sektor primer.

Nilai rata-rata tersebut menunjukkan prosentase cukup tinggi yakni sebesar $61,2 \%$, sehingga hal ini, mengindikasikan bahwa sebagian besar perusahaan sektor primer mengalami kondisi financial distress, karena memiliki nilai debt to asset ratio yang relatif tinggi, sehingga hal ini menunjukkan aset perusahaan banyak didanai oleh utang. Pengelolaan utang perusahaan yang kurang baik dapat memicu terjadinya kondisi gagal bayar, sebagai cikal bakal terjadinya kondisi financial distress.

Hasil penelitian ini konsisten dengan penelitian Yap (2012), Antikasari dan Djuminah (2017) bahwa debt to asset ratio memiliki pengaruh positif dan signifikan terhadap kondisi financial distress perusahaan. Artinya semakin tinggi nilai debt to asset ratio, maka semakin tinggi kemungkinan perusahaan mengalami kondisi financial distress. Penelitian Moleong (2017) juga menegaskan leverage berpengaruh positif signifikan terhadap financial distress, dimana leverage berkontribusi $61 \%$ terhadap perubahan financial distress.

\section{Prediksi Sales Growth Terhadap Financial Distress.}

Berdasarkan hasil pengujian regresi logistik, ditemukan bahwa variabel sales growth tidak mampu memprediksi kondisi financial distress pada perusahaan sektor primer. Hal ini ditunjukkan dengan tingkat signifikansi 0,474 yang lebih besar dari tingkat signifikansi yang ditentukan, yakni sebesar $5 \%$, sehingga hasil ini tidak dapat membuktikan hipotesis.

Pengaruh positif dan tidak signifikan tersebut dapat terjadi karena disaat nilai rata-rata keseluruhan sales growth menyentuh angka $17 \%$, seharusnya perusahaan sektor primer yang mengalami kondisi financial distress tidak terlalu banyak, akan tetapi hal ini justru berbanding terbalik, karena sebagian besar perusahaan sektor primer mengalami kondisi financial distress. Pengaruh tidak signifikan tersebut juga dapat terjadi ketika nilai penjualan suatu perusahaan mengalami penurunan, hal ini tidak secara langsung membuat perusahaan mengalami kebangkrutan, melainkan hanya mengurangi tingkat laba yang dihasilkan.

Hasil penelitian ini mendukung penelitian Widarjo dan Setiawan (2009) yang menyatakan bahwa sales growth memiliki pengaruh negatif dan tidak signifikan terhadap kondisi financial distress perusahaan. Artinya bila nilai sales growth rendah, belum tentu menentukan perusahaan sedang mengalami kondisi financial distress.

\section{SIMPULAN DAN SARAN Simpulan}

Berdasarkan hasil penelitian dan pembahasan, dapat disimpulkan bahwa variabel makroekonomi (sensitivitas nilai tukar dan sensitivitas suku bunga), current ratio, total asset turnover, dan sales growth tidak mampu memprediksikan secara signifikan terhadap financial distress. Namun, profitabilitas yang diproksikan dengan return on asset berpengaruh negatif signifikan terhadap financial distress, dan leverage yang diproksikan dengan debt to asset ratio juga memiliki pengaruh positif signifikan terhadap financial distress pada perusahaan sektor primer yang terdaftar di Bursa Efek Indonesia. 


\section{Saran}

Model prediksi financial distress dapat digunakan sebagai bahan pertimbangan perusahaan sebelum mengambil keputusan manajemen khususnya keputusan keuangan (financial decision) agar tercipta kinerja perusahaan yang baik. Hasil dari penelitian ini juga dapat digunakan sebagai bahan pertimbanagn bagi investor dan calon investor dalam mengambil keputusan investasi pada perusahaan sektor primer yang terdaftar di BEI.

\section{DAFTAR PUSTAKA}

Akbar, A.J., S. Yuliana dan T. Marwa. 2016. Pengaruh Nilai Tukar Rupiah, Suku Bunga SBI, dan Inflasi Terhadap Indeks Harga Saham Gabungan (IHSG) Sektor Pertanian di Bursa Efek Indonesia. Jurnal Ekonomi Pembangunan 14(2): 47-53.

Alafiah, M.N. 2014. Prediction of Financial Distress Companies in the Trading and Services Sector in Malaysia Using Macroeconmic Variables. Procedia Sosial and Behavioral Sciences 129: 90-98.

Almilia, L. S. 2003. Analisis Rasio Keuangan untuk Memprediksi Kondisi Financial Distress Perusahaan Manufaktur yang Terdaftar di Bursa Efek Jakarta. Jurnal Akuntansi dan Auditing Indonesia 7(2): 183-210.

Andre, O. 2013. Pengaruh Profitabilitas, Likuiditas dan Leverage dalam Memprediksi Financial Distress (Studi Empiris Pada Perusahaan Aneka Industri yang Terdaftar di BEI). Jurnal Akuntansi 1(1): 15-26

Andrade, G. and S. N. Kaplan. 1998. How Costly is Financial (not Economic) Distress? Evidence from Highly Leveraged Transactions that Became Distressed. The Journal of Finance 53(5): 1443-1493.

Antikasari, T. W. dan Djuminah. 2017. Prediksi Financial Distress dengan Binary Logit Regression Perusahaan Telekomunikasi. Jurnal Keuangan dan Perbankan 21(2): 265-275
Artha. D. R., N. A. Achsani dan H. Sasongko. 2014. Analisis Fundamental, Teknikal dan Makroekonomi Harga Saham Sektor Pertanian. Jurnal Manajemen dan Kewirausahaan 16(2): 175-184.

Bhattacharjee, A. dan J. Han. 2014. Financial Distress of Chinese forms: Micoeconomic, Macroeconomis and Institusional Influences. China Economic Review 30: 244-262.

Badan Pusat Statistik. 2018. Jumlah Penduduk Bekerja Triwulan I 2018. https:/ / www.google.com/amp/s/amp.tirto.id. Diakses tanggal 3 Agustus 2019.

Brealy, R. A. dan S. C. Myers. 2000. Principle of Corporate Finance. 6th Edition. Boston: Irwin McGraw-Hill.

Brigham, E. F., dan J. F. Houston. 2007. Fundamentals of Financial Management. 10nd ed. Thomson South Western. USA.

Bursa Efek Indonesia 2019. Laporan Keuangan Tahunan Perusahaan Sektor Primer 2014, 2015, 2016, 2017 dan 2018. https:/ / www.idx.co.id [diakses 8 Maret 2019].

Bubic, J. dan J. Hajnrih. 2012. The Analyses Business Performances of Agricultural Enterprises inVojvodina During The Current Crisis. Economics of Agriculture 59: 183 - 194

Darmawan, S. 2017. Analisis Pengaruh Corporate Governance, Variabel Ekonomi Makro terhadap Financial Distress dengan Variabel Kontrol Ukuran Perusahaan dan Jenis Kepemilikan. Efektif Jurnal Ekonomi dan Bisnis 7(1): 100-122

Dwijayanti, P. F. S. 2010. Penyebab, Dampak dan Prediksi dari Financial Distress serta Solusi untuk Mengatasi Financial Distress. Jurnal Akuntansi Kontemporer 2(2): 191-205

Dewi, A. 2015. Manajemen Keuangan Perusahaan. Cetakan Ketiga. Ghalia: Indonesia. Jakarta.

Departemen Kebijakan Ekonomi dan Moneter. 2018. Laporan Kebijakan Moneter Triwulan III 2018. Jakarta 
Djumahir. 2007. Pengaruh Variabel-variabel Mikro dan Variabel-variabel Makro terhadap Financial Distress Pada Perusahaan Industri Food and Beverages yang Terdaftar di Bursa Efek Jakarta. Jurnal Aplikasi Manajemen 5(3): 484 - 492.

Endang dan Jumyetti. 2017. Faktor-Faktor Makro Ekonomi dalam Memprediksi Kondisi Financial Distress. Jurnal Poli Bisnis 8(2).

Fadah, I. 2013. Manajemen Keuangan (Suatu Konsep). Insan Global. Mojokerto.

Farah, M. 2014. Dasar-Dasar Manajemen Keuangan. Dian Rakyat. Jakarta.

Fridayana, Y. 2013. Analisis Regresi dengan Menggunakan Aplikasi Komputer Statistik SPSS. Gramedia Pustaka Utama. Indonesia.

Ghozali, I. 2016. Aplikasi Analisis Multivariate dengan Program IBM SPSS 23. Badan Penerbit Universitas Diponegoro. Semarang.

Gumanti, T. A. 2011. Manajemen Investasi Konsep, Teori dan Aplikasi. Mitra Wacana Media. Jakarta.

Hanifah, O. E. 2013. Pengaruh Struktur Corporate Governance dan Financial Indicators terhadap Kondisi Financial Distress. Diponegoro Journal of Accounting 2(2): 1-15.

Hofer, C. W. 1980. Turnaround Strategies. Journal of Business Strategy 1(19): 31.

Jensen, M. C., dan W. H. Meckling. 1976. Theory of The Firm: Managerial Behavior, Agency Costs And Ownership Structure. Journal of Financial Economics 3(4): 305-360.

Karim, A. A. 2010. Ekonomi Makro Islam. PT. Grafindo Persada. Jakarta.

Kasmir. 2008. Analisis Laporan Keuangan. PT Raja Grafindo Persada. Jakarta.

Koech, E., C. Nyang'aya, dan N M. Robert. 2018. Prediction of Financial Distress in the Light of Financial Crisis : A Chase of Listed Firm in Kenya. International Journal of Economics, Commerce and Management 6(6): 207 - 226

Kunt dan Detragiache. 1997. The determinants of banking crises Evidence from developing and developed countries. International Monetary Fund Working Paper.

Luciana, S.A. 2004. Analisis Faktor-faktor yang Mempengaruhi Kondisi Financial Distress suatu Perusahaan yang Terdaftar di Bursa Efek Jakarta. Jurnal Riset Akuntansi Indonesia (JRAI) 7(1).

Made dan Lely. 2015. Pengaruh Rasio Likuiditas, Leverage, Operating Capacity dan Sales Growth terhadap Financial Distress. E-Jurnal Akuntansi Universitas Udayana 11(2).

Mankiw, N.G. 2000. Teori Makroekonomi. Edisi Keempat. Terjemahan: Imam Nurmawan. Erlangga. Jakarta.

Moleong, L.C. 2017. Pengaruh Real Interest Rate dan Leverage Terhadap Financial Distress. MODUS 30(1): 71-86.

Myers, S. C., dan N. Majluf. 1984. Corporate Financing And Investment Decisions When Firms Have Information Investors Do Not Have. Journal of Financial Economics 13(3): 187-221.

Musthafa. 2017. Manajemen Keuangan. Penerbit ANDI, Anggota IKAPI. Yogyakarta.

Nurhidayah dan Fitriyatur. 2017. Kinerja Keuangan dalam Memprediksi Financial Distress. Jurnal Ilmiah Bisnis dan Ekonomi Asia 11(1).

Platt, H. D., dan Platt, M. B. 2006. Understanding Differences Between Financial Distress and Bankruptcy. Review of Applied Economics 2(2): 141-157.

Platt, H. D., dan Platt, M. B. 2002. Predicting Corporate Financial Distress: Reflections on Choice-Based Sample Bias. Journal of Economics and Finance 26(2): 184-199.

Raissa dan Mariana. 2017. Determinan terhadap Prediksi Financial Distress pada Perusahaan Manufaktur di Bursa Efek Indonesia. Jurnal Riset Ekonomi dan Manajemen 15(2): 371-381.

Rahel, M. A., dan F. T. Kristanti. 2018. Analisis Faktor-Faktor yang Berpengaruh Terhadap Praktik Perataan Laba (Studi Pada Perusahaan Sektor Pertanian Yang Terdaftar Di Bursa Efek 
Indonesia Tahun 2013-2017). Aksara Public 2(4): 161-171.

Ross, S. A. dan Westerfield. 2005. Corporate Finance. McGraw-Hill International Edition

Ross, S. A. 1977. The Determination of Financial Structure: The Incentive Signalling Approach. TheBell Journal of Economics 8(1): 23-40.

Rodoni, A. dan Herni. 2014. Manajemen Keuangan Modern. Mitra Wacana Media. Jakarta.

Riza, M. K. 2018. Analisis Variabel Penjelas Terhadap Kondisi Financial Distress Pada Perusahaan Non-Keuangan yang Terdaftar di Bursa Efek Indonesia. Jurnal Manajemen Bisnis Indonesia (JMBI) 7(5).

Ruhomaun, M. A., M. Saeedi, dan N. Nagavhi. 2019. The Efects of Selected Macro and Mico Economics Variables on Firm Performance for Listed Firms in the Industrial Products Sector in Malaysia. International Jurnal of Recent Technology and Engineering 7(5): $95-101$.

Sapoerti, A. I. 2013. Analisis Pengaruh Keuangan dan Sensitivitas Variabel Ekonomi Makro terhadap Financial Distress Pada Perusahaan Manufaktur. Journal of Economics, Business, \& Accountancy Ventura 16(3): 36-47

Scott, W. R. 2015. Financial Accouting Theory $7^{\text {th }}$ Edition. Pearson. Toronto.

Sofyan dan Heri. 2014. SPSS Complete. Salemba Infotek. Jakarta.

Sulaksana, T. 2016. Analisis Rasio Keuangan dan Variabel Ekonomi Makro dalam Memprediksi Financial Distress Per- usahaan Pertambangan di Bursa Efek Indonesia Periode 2011-2015. Thesis. STIE Perbanas Surabaya.

Tuvaratragool, S. 2013. The Role of Financial Ratios in Signaling Financial Distress: Evidence From Thai Listed Companies. Thesis. Graduate College of Management South.

Veronica, M. S. dan S. P. D. Anantadjaya. 2014. Banckruptcy Prediction Model: An Industrial Study in Indonesia PubliclyListed Firms During 1999 - 2001. Review of Integrative Business $\mathcal{E}$ Economics Research 3(1): 13-41

Widarjo, W. dan D. Setiawan. 2009. Pengaruh Rasio Keuangan terhadap Kondisi Financial Distress Perusahaan Otomotif. Jurnal Bisnis dan Akuntansi 11(2): 107-119.

Whitaker, R. B. 1999. The Early Stages of Financial Distress. Journal of Economics and Finance 23 (2): 123-133.

Wruck, K. H. 1990. Financial Distress, Reorganization and Organizational Efficiency. Journal of Financial Economics 27: 419-444.

Yap, B. C. F. 2012. Evaluating Company Failure in Malaysia Using Financial Ratios and Logistic Regression. Asian Journal of Finance and Accounting 4(1): 330-344.

Yulpa. 2017. Pengaruh Current Ratio, Debt to Total Asset Ratio dan Total Asset Turnover terhadap Kondisi Financial Distress. E-Journal Administrasi Bisnis 5(4): 855-866. 